\title{
The Principles of Exercise Therapy M Dena Gardiner Delhi, India CBS Publishers \& Distributor
}

\author{
Wajida Perveen* \\ Department of Physical Therapy, University of Sargodha, Pakistan
}

Submission: November 01, 2017; Published: November 15, 2017

*Corresponding author: Wajida perveen, University of Sargodha, Sialkot College of Physical Therapy, amin welfare \& Teaching Hospital, defence road, Pakistan, Tel: 0092-333-3507157; Email: wjda_noor@yahoo.com

\section{Mini Review}

It was a wonderful experience to review this small and informative book. The primary purpose of this book is to help and guide the beginners in Physical Therapy, Occupational Therapy \& Physical Education generally and in Kinesiology particularly and further to assist them in understanding the Human Movements. M. Dena Gardiner was Deputy Principal of the London school of Physiotherapy where she taught from 19431960. She earned Diploma in Physical Education and the double teachers' qualification in Chartered Society of Physiotherapy. She dedicated this book to her students. She died in 1978 and the book was completed and published by her colleagues at London school of Physiotherapy in 1985. Pocket Book of Exercise Therapy, was her best work, according to herself [1].

The book contains Table of Contents, Bibliography and Index. Appendices include Derived Positions and Terminology. Notes on conflict of interest and publication ethics are also added. The volume of 302 pages is divided into 22 chapters. Most of the chapters are a continuum of the previous one and are self-explanatory to the previous chapter. Each chapter begins with brief introduction outlining the background and aims of the reading followed by the sequential, appropriate and relevant details of the topics. Although the summary is missing by the end of the chapter, yet the last passages of every chapter include information to be explored more with keen interest.

The content and preview of the book is supported by headings and sub headings. Captions and labels are accurate, informative and supplement the main ideas. The writing style is descriptive in British English, but at few points students find it hard to understand. Neither Side bars nor topic sentences and section/ chapter previews are included which may help the readers to absorb main ideas. Extension activities are also not included. The page layout is black and white, simple and weekly supported by thematic images. The book is a hardcopy with paper back. The book includes real life applications with no gender biasness; the therapist is considered to be female and the patient being a male. The topics integrate the background knowledge of Anatomy, Physiology, Neurology and Mechanics.

The book is used as a text book in the disciplines of Physical Therapy, Occupational Therapy, Physical Rehabilitation and Physical Education not only in Indo-Pak but all over the world in the very beginning years of their graduate degrees. The book buildup back ground knowledge of the students to understand Biomechanics, Ergonomics, Manual therapy, Therapeutic Exercises \& Techniques, Physiotherapy Treatment, exercise physiology and many more theoretical concepts and practical skills in successive classes/ semesters of their respective disciplines. Although the syllabus of Kinesiology depends greatly on this knowledge bank still no separate hand book for teachers is provided. A brief yet compact book it is. Many other colorful, informative, innovative and aesthetically pleasing books in kinesiology are available in the market but no book could replace it. Even experienced subject specialists will find basis for many subjects in the respective field.

\section{References}

1. M Dena Gardiner (1985) The Principles of Exercise Therapy. ( $4^{\text {th }}$ edn) India CBS Publishers. Pages. 302. 

(C) This work is licensed under Creative BY DOI:10.19080/GJARM.2017.04.555640
Your next submission with Juniper Publishers will reach you the below assets

- Quality Editorial service

- Swift Peer Review

- Reprints availability

- E-prints Service

- Manuscript Podcast for convenient understanding

- Global attainment for your research

- Manuscript accessibility in different formats

( Pdf, E-pub, Full Text, Audio)

- Unceasing customer service

Track the below URL for one-step submission https://juniperpublishers.com/online-submission.php 